\title{
PENINGKATAN LEARNING ORGANIZATION MELALUI KEPEMIMPINAN TRANSFORMASIONAL DAN EFIKASI DIRI GURU SMP SWASTA BUDDHIS SE-PROVINSI BANTEN
}

\author{
Hendri Ardianto $^{a)}$, Widodo Sunaryo ${ }^{b)}$, Sumardi ${ }^{\left.b^{*}\right)}$ \\ ${ }^{a)}$ SMP Swasta Buddhis se Provinsi Banten, Banten, Indonesia \\ b) Universitas Pakuan, Bogor, Indonesia \\ ${ }^{*}$ e-mail korespondensi: sumardi@unpak.ac.id
}

riwayat artikel : diterima: 06 November 2019; direvisi: 16 November 2019; disetujui: 06 Desember 2019

\begin{abstract}
Abstrak. Penelitian ini bertujuan untuk menemukan upaya bagaimana learning organization dapat ditingkatkan dengan cara meneliti hubungan learning organization dengan kepemimpinan transformasional dan efikasi diri. Penelitian ini dilakukan menggunakan pendekatan kuantitatif dengan metode statistik korelasional untuk mengetahui apakah kepemimpinan transformasional dan efikasi diri memiliki hubungan positif dengan learning organization. Sampling dalam penelitian ini menggunakan teknik proportional random sampling dengan rumus taro yamane. Dalam penelitian ini pengumpulan data menggunakan angket (questionnaire). Kemudian dilakukan analisis dengan menggunakan metode Sitorem untuk memberikan rekomendasi dan menentukan urutan prioritas perbaikan yang perlu dilakukan. Penelitian ini dilakukan pada guru SMP Swasta Buddhis se Provinsi Banten dengan populasi penelitian 145 dan sampel 107 guru. Hasil penelitian menunjukkan bahwa terdapat hubungan positif kepemimpinan transformasional dengan learning organization dengan kekuatan hubungan $\mathrm{r}_{\mathrm{y} 1}=0,530$ dan terdapat hubungan positif efikasi diri dengan learning organization dengan kekuatan $r_{\mathrm{y} 2}=0,477$. Temuan menunjukkan bahwa learning organization dapat ditingkatkan melalui pengembangan kepamimpinan transformasional dan efikasi diri. Analisis Sitorem menunjukkan bahwa komponen kepemimpinan transformasional, efikasi diri dan learning organization merekomendasikan 10 indikator yang perlu diperbaiki yaitu: 1) Individualized consideration, 2) Keyakinan pada pemahaman akan kemampuannya, 3) Komitmen dan tekat dari semua orang dalam organisasi, 4) Pola berpikir sistematik, 5) Keterampilan individu, 6) Sikap tim berorganisasi, 7) Membuat generalisasi, 8) Gambaran masa depan yang ideal, 9) Visi yang disepakati oleh seluruh anggota organisasinya dan 10) Sikap dewasa (maturity).
\end{abstract}

Kata Kunci: Learning Organization, Kepemimpinan Transformasional dan Efikasi Diri.

\section{IMPROVEMENT OF LEARNING ORGANIZATION THROUGH TRANSFORMATIONAL LEADERSHIP AND EFICATION OF TEACHER OF BUDDHIS PRIVATE SCHOOL BANTEN PROVINCE}

\begin{abstract}
The purpose of this study was to find that learning organization can be improved by examining the relationship of learning organization, transformational leadership and self-efficacy. This research was conducted with a quantitative approach by using correlational statistical methods to determine whether transformational leadership and self-efficacy have a positive relationship with learning organization. Sampling in this study was using proportional random sampling technique with the taro yamane formula. The data collection to measuring instruments was a questionnaire. The results were continually analyzed by using the SITOREM methods in order to derive recommendations and determine the order of priority improvements that need to be made. This research was conducted on Buddhist Private Middle School teachers in Banten Province with a study population of 145 and a sample of 107 teachers. The results showed that there was a positive relationship between transformational leadership and learning organization with a relationship strength of ry $1=0,530$ and there was a positive relationship between self-efficacy and learning organization with a strength of ry $2=0,477$. This shows that learning organizations can be improved through the development of transformational leadership and self-efficacy. Sitorem's analysis results showed that in the components of transformational leadership, self-efficacy and learning organization were found 10 indicators that need to be improved, namely: 1) Individualized consideration, 2) Confidence in understanding his / her abilities, 3) commitment and determination of everyone in the organization, 4) Systematic thinking patterns, 5) Individual Skills, 6) Organizational team attitude, 7) Make generalizations, 8) A conception of an ideal future, 9) A vision which agreed upon by all members of the organization and 10) Maturity.
\end{abstract}

Keywords: learning organization; transformational leadership; self-efficacy

\section{PENDAHULUAN}

Pada era kompetisi ketat saat ini, seluruh organisasi berupaya melakukan strategi paling efektif untuk dapat bertahan dan berkembang. Salah satu strategi bertahan yang relatif banyak dipilih berbagai organisasi adalah dengan penguatan learning organization $(L O)$, dimana seluruh warga organisasi terus-menerus melakukan perbaikan kinerja di segala lini. Organisasi pembelajar bercirikan aktivitas organisasi dalam melakukan pengembangan kemampuan anggotanya, untuk melakukan perubahan terus menerus, melakukan berbagai eksperimen yang dapat mendukung tercapainya tujuan organisasi. organisasi 
berfungsi untuk menciptakan rasa identitas bagi anggota organisasi, memfasilitasi munculnya kolektif komitmen anggota organisasi, meningkatkan sistem sosial stabilitas, dan menciptakan mekanisme makna serta kontrol yang memandu sikap dan perilaku anggota organisasi (Suchyadi, 2017). Organisasi yang disiplin melakukan LO umumnya senantiasa memperbaiki produk dan layanannya, mengoptimalkan potensi-potensi warganya sehingga secara umum kualatas SDM meningkat.

Sekolah yang bertransformasi menjadi learning organization ditandai dengan kuatnya penetapan dan pengembangna visi bersama yang kemudian menjadi pengarah akurat kemana sekolah menuju. Ciri lainnya adalah warga sekolah memiliki pandangan positif dan konstruktif terhadap fenomena di sekelillingnya, bahkan kegagalan sekalipun dapat dijadikan bahan belajar untuk melakukan perbaikan. Sekolah yang mengembangkan LO akan menggunakan pendekatan sistemik dalam menghadapi permasalahan dan menyusun rencana strategis sehingga tingkat adaptasinya terhadap perubahan eksternal terus meningkat. Sekolah yang mengembangkan LO warganya akan bekerja sama sebagai tim bahu membahu

Demikian signifikan dampak LO terhadap pengembangan organisasi, namun fakta di lapangan belum sebagaimana diharapkan. Survei pendahuluan yang dilakukan kepada 5 Kepala Sekolah Menengah Pertama Swasta Buddhis di Provinsi Banten yang memberikan penilaian terhadap 30 guru, terdapat beberapa masalah berkenaan learning organization. Ditemukan masih terdapat $41 \%$ guru bermasalah pada dimensi personal mastery, $49 \%$ bermasalah pada dimensi berbagi visi, $40 \%$ bermasalah pada dimensi mental model, $39 \%$ bermasalah pada dimensi pembelajaran tim, dan $45 \%$ bermasalah pada dimensi berpikir sistemik. Kondisi ini membutuhkan kajian komprehensif guna menemukan upaya-upaya meningkatkan learning organization melalui faktor-faktor yang diduga mempunyai hubunga khususnya kepemimpinan transformasional dan efikasi diri.

\section{Learning Organization}

Rumusan leraning organization dinyatakan Robbins (2008:8) sebagai suatu organisasi yang terus berupaya mengembangkan kemampuan dan kapabilitas pada lingkungan yang berubah. Pernyataan serupa dikemukakan Daft (2010:50) yang berpendapat bahwa learning organization adalah organisasi yang anggota-anggotanya terlibat dalam mengidentifikasi dan menyelesaiakan masalah, sehingga organisasi dapat terus menerus melakukan perubahan dan memperbaiki diri dengan tujuan meningkatkan kemampuan untuk tumbuh, belajar dan mencapai tujuannya. Tshosane (2011:57) mengemukakan bahwa learning organization adalah organisasi yang mempromosikan pembaruan organisasi yang berkelanjutan dengan menanamkan serangkaian proses inti yang memelihara kecenderungan untuk belajar, beradaptasi dan berubah.

Penelitian Saeeda, Mammona, Fahmeeda, dan Aijaz (2015:93) menghasilkan sintesis organisasi pembelajar sebagai sekelompok orang yang memiliki kemampuan belajar terus-menerus, sebuah organisasi di mana proses pembelajaran dianalisis, disaring, dibangun, dan disatukan dengan tujuan dan sasaran yang ditetapkan. Daft (2010:66) mendefinisikan organisasi pembelajaran (learning organization) adalah organisasi yang didalamnya semua orang berupaya mengenali dan memecahkan masalah sehingga memungkinkan organisasi tersebut untuk senantiasa bereksperimen, berubah dan melakukan peningkatan guna meningkatkan kemampuan berkembang, belajar dan mencapai tujuan.

Berdasarkan konsep-konsep yang telah diuraikan, dapat disintesiskan bahwa yang dimaksud learning organization adalah upaya pengembangan yang dilakukan oleh organisasi kepada para anggotanya untuk melakukan perubahan dengan terus menerus belajar serta bereksperimen demi terealisasinya tujuan organisasi. Indikator-indikatornya adalah: 1. Komitmen dan tekad semua orang di dalam organisasi, 2. Pola berpikir sistemik, 3. Ketrampilan individu, 4. Keyakinan atas kemampuannya, 5. Konsentrasi energi, 6. Sikap tim berorganisasi, 7. Membuat generalisasi, 8. Visi yang disepakati oleh seluruh anggota organisasi, 9. Gambaran masa depan yang ideal, 10. Sikap dewasa (maturity)

\section{Kepemimpinan Transformasional}

Menurut Bass dan Riggio (2006:4) kepemimpinan transformasional adalah perilaku pemimpin yang melibatkan inspirasi pengikut untuk berkomitmen dalam visi dan tujuan organisasi atau unit organisasi, dan menantang mereka untuk mampu memecahkan masalah secara inovatif, mengembangkan kapasitas kepemimpinan melalui pembinaan, pendampingan, serta menyediakan baik tantangan maupun dukungan untuk mencapai tujuan bersama. Sejalan dengan pendapat tersebut, Colquitt $e t$ al (2009:448) merumuskan kepemimpinan transformasional sebagai tindakan seorang pemimpin yang melibatkan inspirasi seluruh anggotanya untuk berkomitmen dalam rangka menuju visi bersama yang memberikan makna terhadap pengembangan potensi mereka sendiri dan beberapa permasalahan dari perspektif baru.

Kinicki dan Williams (2008: 44) mendefinisikan kepemimpinan trasformasional adalah perilaku pemimpin yang mengubah karyawan untuk mengejar tujuan organisasi melebihi kepentingan pribadi. Pemimpin transformasional akan berusaha untuk mempengaruhi, menggerakkan dan mengembangkan kepemimpinannya kepada orang lain. Yulk (2004: 312-313) mendefinisikan kepemimpinan transformasional adalah perilaku pemimpin yang menumbuhkan rasa percaya pengikutnya, kekaguman, kesetiaan dan rasa hormat terhadap pemimpin serta termotivasi untuk melakukan lebih dari harapan awal.

Berdasarkan konsep-konsep yang telah diuraikan, dapat disintesiskan bahwa yang dimaksud kepemimpinan transformasional adalah perilaku seorang pemimpin yang mampu membawa organisasinya kearah yang baik dan memberi inspirasi pada pengikutnya dengan inovasi serta mendukung pengikutnya mengembangkan potensi demi visi organisasi. Indikator-indikatornya adalah: 1. Inspirational motivation, 2. Idealized influence, 3. Individualized consideration, dan 4. Intellectual simulation. 


\section{Efikasi Diri}

Pengertian efikasi diri dikemukakan Boyd dan Helen (2008:281) sebagai keyakinan seseorang terhadap kapasitasnya untuk menyebabkan sesuatu yang diinginkannya terjadi atau menjadi kenyataan. Kreitner and Kinicki (2010: 129-130) mendefinisikan efikasi diri adalah keyakinan seseorang mengenai kesempatannya untuk berhasil menyelesaikan tugas tertentu. Jess, Gregory dan Robert (2010: 86) mendefinisikan efikasi diri sebagagi keyakinan seseorang terhadap kemampuannya untuk menggunakan sejumlah kontrol fungsi diri mereka sendiri dan lingkungannya.

McShane dan Von Glinow (2010:45) mengemukakan rumusan efikasi diri sebagai keyakinan seseorang bahwa ia dapat berhasil menyelesaikan suatu tugas. Mereka yang mempunyai efikasi diri tinggi, mempunyai sikap "can do". Pengertian efikasi diri dinyatakan Fred Luthans (2011:203) sebagai keyakinan seseorang mengenai kemampuannya untuk memobilisasi motivasi, sumber-sumber kognitif dan tindakan nyata yang dibutuhkan untuk berhasil melaksanakan tugas khusus pada situasi tertentu. Efikasi diri merupakan keyakinan sesorang untuk dapat melakukan sesuatu dengan berhasil (Hidayat, 2017)

Berdasarkan uraian definisi di atas dapat disintesiskan bahwa yang dimaksud dengan efikasi diri adalah kepercayaan individu dalam menuntaskan tugasnya dengan sumber-sumber kognitif dan tindakan nyata yang dibutuhkan. Indikatorindikatornya adalah: 1. Keyakinan mengatasi masalah, 2. Keyakinan meraih keberhasilan, 3. Keyakinan pada pemahaman akan kemampuan, 4. Mampu memahami kemampuan dirinya terbatas pada situasi tertentu yang bervariasi, 5. Pengharapan kuat kemampuan diri mendorong mencapai keberhasilan, 6 . Mengerjakan tugas yang dirasa mampu.

\section{METODE PENELITIAN}

Penelitian ini menggunakan metode kuantitatif dengan metode survei korelasional. Variabel bebas dalam penelitian ini yaitu kepemimpinan transformasional $\left(\mathrm{X}_{1}\right)$ dan efikasi diri $\left(\mathrm{X}_{2}\right)$, sedangkan variabel terikat $(\mathrm{Y})$, adalah learning organization. Populasi dalam penelitian ini yaitu Guru honorer SMP Swasta Buddhis se Provinsi Banten. Dengan menggunakan teknik proporsional random sampling dan rumus Taro Yamane, diperoleh sampel penelitian sebanyak 107 orang.

Data hasil penelitian kuntitatif dianalisis menggunakan statistik deskriptif dan statistik inferensial. Statistik inferensial yang menggunakan analisis regresi-korelasi. Analisis data diawali dengan analisis persyaratan analisis, yaitu: uji normalitas galat taksir dan uji hogenitas varian.kemudian dilanjutkan dengan penetapan persamaan regresi, uji signifikansi persamaan regresi, linearitas regresi serta pengujian hipotesis dengan uji korelasi menggunakan tabel ANAVA. Hasil data di lapangan pun akan dikelompokkan per indikator sehingga dapat dibandingkan dan dianalisis dengan menggunakan metode SITOREM.

\section{HASIL DAN PEMBAHASAN}

\section{Pengujian Persyaratan Analisis}

\section{Uji Normalitas}

Syarat data sampel berasal dari populasi berdistribusi normal adalah jika $\mathrm{L}_{\text {hitung }}<\mathrm{L}_{\text {tabel }}$ dengan taraf signifikan 0,05 . Hasil perhitungan normalitas galat taksiran variabel learning organization atas kepemimpinan transformasional diperoleh nilai $\mathrm{L}_{0}$ maksimum 0,084 sementara $\mathrm{L}_{\mathrm{t}}$ sebesar 0,086. Dengan demikian galat baku taksiran variabel learning organization atas variabel kepemimpinan transformasional berdistribusi normal.

Hasil perhitungan normalitas galat taksiran variabel learning organization atas efikasi diri diperoleh nilai L0 maksimum 0,048 sementara Lt sebesar 0,086. Dengan demikian galat baku taksiran variabel learning organization atas variabel efikasi diri berdistribusi normal..

\section{Uji Homogenitas}

Syarat varians homogen adalah jika $\chi_{\text {hitung }}^{2}<\chi_{\text {tabel }}^{2}$ dengan taraf signifikansi 0,05 . Hasil homogenitas varians variabel learning organization atas kepemimpinan transformasional diperoleh nilai $\chi_{\text {hitung }}^{2}$ sebesar 39,92 sedangkan $\chi_{\text {tabel }}^{2}$ pada taraf signifikansi 5\% sebesar 132,14, sehingga dapat disimpulkan bahwa kelompok data learning organization atas variabel kepemimpinan transformasional berasal dari populasi yang homogen.

Hasil homogenitas varians variabel learning organization atas efikasi diri diperoleh nilai $\chi_{\text {hitung }}^{2}$ sebesar 34,08 sedangkan $\chi_{\text {tabel }}^{2}$ pada taraf signifikansi $5 \%$ sebesar 132,14. dikarenakan $\chi_{\text {hitung }}^{2}<\chi_{\text {tabel, }}^{2}$ dapat disimpulkan bahwa kelompok data learning organization atas variabel efikasi diri berasal dari populasi yang homogen.

\section{Pengujian Hipotesis}

\section{Hubungan Antara Kepemimpinan Transformasional $\left(\mathrm{X}_{1}\right)$ dengan Learning Organization $(\mathbf{Y})$.}

Dari hasil perhitungan analisis korelasi, diketahui bahwa nilai koefesien korelasi antara kepemimpinan transformasional dengan learning organization, sebesar 0,530 dan nilai $t_{\text {hitung }}$ sebesar 7,56 serta nilai $t_{\text {tabel }}$ sebesar 1,98. Oleh karena itu nilai $t_{\text {hitung }}$ lebih besar dari nilai $\mathrm{t}_{\text {tabel }}$ maka dengan demikian $\mathrm{H}_{0}$ ditolak dan $\mathrm{H}_{1}$ diterima. Artinya bahwa terdapat hubungan positif antara kepemimpinan transformasional dengan learning organization 


\section{Hubungan antara Efikasi Diri $\left(\mathrm{X}_{2}\right)$ dengan Learning Organization (Y).}

Dari hasil perhitungan analisis korelasi, diketahui nilai koefesien korelasi antara efikasi diri dengan learning organization, sebesar 0,476 dan nilai $t_{\text {hitung }}$ sebesar 6,32 serta nilai $t_{\text {tabel }}$ sebesar 1,98 . Oleh karena itu nilai $t_{\text {hitung }}$ lebih besar dari nilai $\mathrm{t}_{\text {tabel }}$ maka dengan demikian $\mathrm{H}_{0}$ ditolah dan $\mathrm{H}_{1}$ diterima. Artinya bahwa terdapat hubungan positif antara efikasi diri dengan learning organization.

3. Hubungan antara Kepemimpinan Transformasional $\left(\mathbf{X}_{1}\right)$ dan Efikasi Diri $\left(\mathbf{X}_{2}\right)$ secara bersama-sama dengan Learning Organization (Y)

Korelasi variabel kepemimpinan transformasional $\left(\mathrm{X}_{1}\right)$ dan efikasi diri $\left(\mathrm{X}_{2}\right)$ secara bersama-sama dengan learning organization $(\mathrm{Y})$ ditentukan oleh nilai koefesien determinasi $\left(\mathrm{r}_{\mathrm{y} 12}^{2}\right)$. Nilai koefesien determinasi menunjukkan besarnya kontribusi variabel kepemimpinan transformasional $\left(\mathrm{X}_{1}\right)$ dan efikasi diri $\left(\mathrm{X}_{2}\right)$ dapat mempengaruhi variabel learning organization (Y). Berdasarkan hasil estimasi diperoleh nilai $\mathrm{r}_{\mathrm{y} 12}^{2}$ sebesar 0,288 . Hal ini menunjukkan bahwa $28,8 \%$ variabel learning organization $(\mathrm{Y})$ dapat dipengaruhi oleh variabel kepemimpinan transformasional $\left(\mathrm{X}_{1}\right)$ dan efikasi diri $\left(\mathrm{X}_{2}\right)$. Resistensi hubungan diantara variabel kepemimpinan transformasional $\left(\mathrm{X}_{1}\right)$ dan efikasi diri $\left(\mathrm{X}_{2}\right)$ secara bersama-sama dengan variabel learning organization $(\mathrm{Y})$ ditentukan oleh koefesien korelasi $\mathrm{r}_{\mathrm{y} 12}$ sebesar 0,537.

Pengujian hipotesis yang membuktikan terdapat hubungan positif variabel kepemimpinan transformasional $\left(\mathrm{X}_{1}\right)$ dan efikasi diri $\left(\mathrm{X}_{2}\right)$ secara bersama-sama dengan variabel learning organization $(\mathrm{Y})$ diperlukan uji signifikan koefesien korelasi dengan menggunakan uji F. tolak ukur pengujian signifikan koefesien yaitu $\mathrm{F}_{\text {hitung }}>\mathrm{F}_{\text {tabel }}$.

\section{Korelasi Parsial}

Hasil uji korelasi parsial antara kepemimpinan transformasional $\left(\mathrm{X}_{1}\right)$ dengan learning organization $(\mathrm{Y})$ dan efikasi diri $\left(\mathrm{X}_{2}\right)$ dikontrol oleh koefisien korelasi parsial $\left(\mathrm{ry}_{12}\right)=0,282$. Berdasarkan uji signifikansi, nilai tersebut sangat signifikan bahwa $\mathrm{t}_{\text {hitung }}(3,40)$ lebih besar dari $\mathrm{t}_{\text {tabel }}$ pada taraf signifikasi $0,05(1,98)$. Hal ini berarti bahwa hubungan antara kepemimpinan transformasional $\left(\mathrm{X}_{1}\right)$ dengan learning organization $(\mathrm{Y})$ tidak dipengaruhi secara signifikan oleh efikasi diri $\left(\mathrm{X}_{2}\right)$.

Hasil uji korelasi parsial antara efikasi diri $\left(\mathrm{X}_{2}\right)$ dengan learning organization $(\mathrm{Y})$ dan kepemimpinan transformasional $\left(\mathrm{X}_{1}\right)$ dikontrol oleh koefisien korelasi parsial $\left(\mathrm{ry}_{21}\right)=0,099$. Berdasarkan uji signifikansi, nilai tersebut tidak signifikan, bahwa $t_{\text {hitung }}(1,07)$ lebih kecil dari $t_{\text {tabel }}$ pada taraf signifikasi $0,05(1,98)$. Hal ini berarti variabel kepemimpinan transformasional $\left(\mathrm{X}_{1}\right)$ berpengaruh secara signifikan terhadap hubungan antara efikasi diri $\left(\mathrm{X}_{2}\right)$ dan learning organization $(\mathrm{Y})$.

\section{Pembahasan}

\section{Hubungan Kepemimpinan Transformasional dengan Learning Organization}

Kekuatan hubungan kepemimpinan transformasional dengan learning organization dapat terlihat pada hasil uji korelasi dengan nilai koefesien sebesar 0,530. Keragaman yang ada pada learning organization memiliki kaitan dengan kepemimpinan transformasional, hal tersebut dapat dilihat dari nilai koefesien determinasi sebesar 0,281 sehingga keragaman yang ada pada learning organization dapat dijelaskan oleh kepemimpinan transformasional dengan kontribusi sebesar $28,1 \%$. Sedangkan $71,9 \%$ dipengaruhi oleh faktor lain diluar kepemimpinan transformasional. Atas hasil penelitian tersebut, kepala sekolah dengan menunjukkan idealized influence (karisma), inspirational motivation, intellectual stimulation, dan individualized consederation mendukung learning organization yang efektif.

Hasil diatas sejalan dengan hasil penelitian yang dilakukan oleh Fazlollah Zarepour Nasirabadi, Elham Vahedi dan Mahdi Vahedi (2014: 31) berjudul "The Relationship between the Learning Organization Dimensions and Transformational Leadership in Petrochemical Industry in Iran". Ada hubungan yang signifikan antara kepemimpinan transformasional dan organisasi pembelajaran. Menurut uji korelasi Pearson, korelasi signifikan pada tingkat 0,05, Artinya ada hubungan yang signifikan antara kepemimpinan transformasional dan pembelajaran organisasi berada pada 0,95 derajat kepercayaan. Semaikin tinggi transformasional leadership, diprediksi akan semakin tinggi pula peningkatan learning organization.

\section{Hubungan Efikasi Diri dengan Learning Organization}

Kekuatan hubungan efikasi diri dengan learning organization dapat terlihat pada hasil uji korelasi dengan nilai koefesien sebesar 0,476 . Keragaman yang ada pada learning organization memiliki kaitan dengan efikasi diri, hal tersebut dapat dilihat dari nilai koefesien determinasi sebesar 0,227 sehingga keragaman yang ada pada learning organization dapat dijelaskan oleh efikasi diri dengan kontribusi sebesar 22,7\%. Sedangkan 77,3\% dipengaruhi oleh faktor lain diluar efikasi diri. Berdasarkan hasil tersebut, maka kepercayaan individu dalam menuntaskan tugasnya dengan sumber-sumber kognitif dan tindakan nyata sangatlah mendukung terjadinya organisasi pembelajaran yang baik. Hal tersebut dapat disimpulkan bahwa terdapat hubungan positif efikasi diri dengan learning organization, sehingga efikasi diri merupakan salah satu faktor penting dalam upaya meningkatkan learning organization.

Hasil tersebut sejalan dengan hasil penelitian Dian Wulandari, Billy Tunas, dan Widodo Sunaryo (2017: 29) berjudul "Relationship between Knowledge Management, Empowerment and Self Efficacy to Learning Organization”. Memberikan kesimpulan bahwa terdapat hubungan positif yang signifikan antara Self-Efficacy dan Learning Organization dengan koefisien korelasi $(r)=0,214(\rho<0,01)$. Berdasarkan koefisien determinasi $\left(r^{2}\right)=0,046$, disimpulkan bahwa self-efficacy menyumbang $4,6 \%$ dari organisasi pembelajaran. Semaikin tinggi self-efficacy guru, semakin tinggi pula peningkatan learning organization. 


\section{Hubungan Kepemimpinan Transformasional dan Efikasi Diri Secara bersama-sama dengan Learning Organization.}

Kekuatan hubungan kepemimpinan transformasional dan efikasi diri secara bersama-sama dengan learning organization dapat terlihat pada hasil uji korelasi dengan nilai sebesar 0,537. Keragaman yang ada pada learning organization memiliki kaitan dengan kepemimpinan transformasional dan efikasi diri yang terlihat dari nilai koefesien determinasi sebesar 0,288. Sehingga keragaman yang ada pada learning organization dapat dijelaskan oleh kepemimpinan transformasional dan efikasi diri dengan kontribusi sebesar $28 \%$ faktor learning organization ditentukan secara bersama-sama oleh kepemimpinan transformasional dan efikasi diri. Ada lima aspek yang harus ditinjau untuk meningkatkan learning organization yaitu: 1) model mental, 2) kepiawaian pribadi, 3) visi bersama, 4) tim pembelajaran, dan 5) berpikir serba system.

Selain itu seberapa besar kekuatan hubungan antara variabel bebas dan variabel terikat serta untuk mendapatkan solusi optimal dari penelitian ini dapat dilihat pada gambar konstelasi penelitian dan statistic berdasarkan analisis Scientific Identification Theory To Conduct Operation Research In Education Management (SITOREM). Teori pengenalan ilmiah untuk riset operasi di bidang manajemen pendidikan untuk menentukan penurunan saran atau rekomendasi hasil penelitian (Hardhienata, 2017) seperti yang ditunjukkan pada gambar 1.
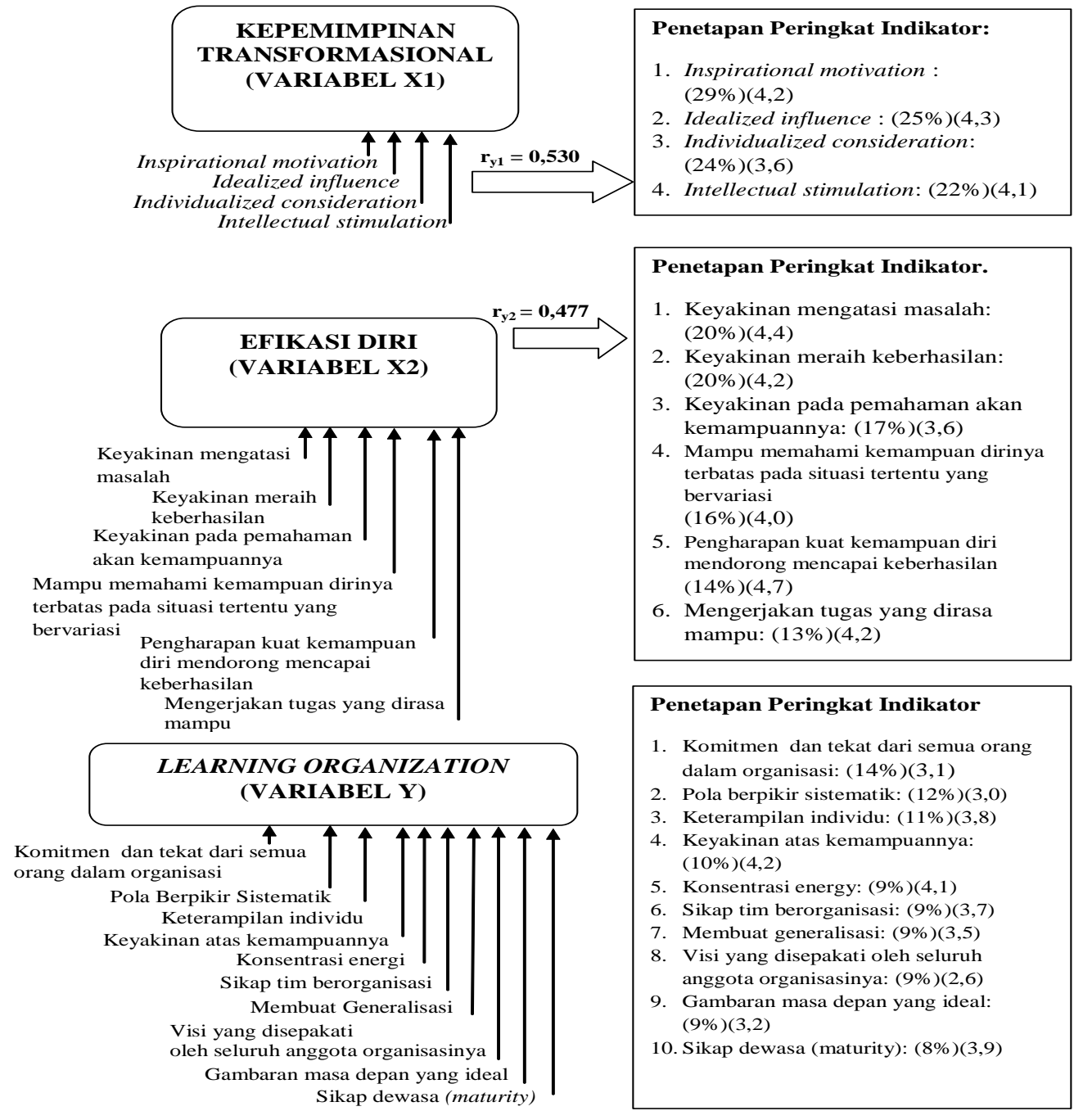

Gambar 1. Rekapitulasi Hasil Analisis SITOREM

\section{SIMPULAN}

Hasil penelitian menunjukkan bahwa terdapat hubungan yang positif dan signifikan antara kepemimpinan transformasional dengan learning organization dengan kekuatan hubungan $r_{y 1}=0,530$ dan terdapat hubungan yang positif antara efikasi diri dengan learning organization, dengan kekuatan hubungan $\mathrm{r}_{\mathrm{y} 2}=0,477$. Hal ini mencerminkan bahwa, untuk 
meningkatkan learning organization guru dilakukan upaya dengan cara meningkatkan kepemimpinan transformasional dan efikasi diri.

Hasil analisis SITOREM menunjukkan bahwa komponen kepemimpinan transformasional, efikasi diri dan learning organization ditemukan 10 indikator untuk dilakukan perbaikan yaitu: 1) Individualized consideration, 2) Keyakinan pada pemahaman akan kemampuannya, 3) Komitmen dan tekat dari semua orang dalam organisasi, 4) Pola berpikir sistematik, 5) Keterampilan individu, 6) Sikap tim berorganisasi, 7) Membuat generalisasi, 8) Gambaran masa depan yang ideal, 9) Visi yang disepakati oleh seluruh anggota organisasinya, dan 10) Sikap dewasa (maturity).

\section{REFERENSI}

Bass, B.M, and R.E Riggio. (2006). Transformational Leadership. London: Lawrence Erlbaum Associates Publishers. Boyd, Denise., \& Helen Bee. (2008). Lifespan development (4th ed). United States of America: Pearson Education, Inc Colquit, Le Pine, Wesson.(2009). Organizational Behavior.New York:Mc Graw Hill Daft, Richard L. (2010). New era of Management, $9^{\text {th }}$ Ed, South Western: Cengage Learning.

Fazlollah Zarepour Nasirabadi, Elham Vahedi and Mahdi Vahedi. (2014). The Relationship between the Learning Organization Dimensions and Transformational Leadership in Petrochemical Industry in Iran. Research Journal of Recent Sciences. Vol. 3(9)

Hardhienata, Soewarto. (2017). The development of scientific identification theory to conduct operation research in education management. IOP Conference Series: Material Science and Engineering. Vol 166.

Hidayat, Rais. (2017). Perilaku Etis Dosen Dalam Perspektif Efikasi Diri, Kepemimpinan, Dan Komunikasi Interpersonal. Pedagonal| Jurnal Ilmiah Pendidikan. Vo. 1 No.1. 2017.

Jess, Feist dan Feist, Gregory J. 2010. Teori Kepribadian, Theories of Personality Buku 2 Edisi7 . Jakarta: Salemba Humanika.

Kinicki, A. \& Williams, B. (2008). Management, A Practical Introduction, Third Edition, New York, NY: Mcgraw-Hill.

Kreitner, Robert dan A. Kinicki. (2010). Organizational Behavior. New York: McGraw-Hill.

Luthans, Fred. 2011. Organizational Behavior : An Evidence-Based Approach. New York: McGraw-Hill.

McShane, Steven L dan Von Glinow, Mary A. (2010). Organizational Behaviour-Emerging Knowledge andPractice For The Real World 5thEdition. New York : McGraw-Hill

Robbins, S. (2008). Perilaku Organisasi, Jilid I dan II, alih Bahasa : Hadyana Pujaatmaja. Jakarta: Prenhallindo.

Saeeda, Mammona, Fahmeeda, Aijaz. 2015. LEARNING ORGANIZATION-Conceptual and Theoretical Overview. International Journal of Humanities Social Sciences and Education (IJHSSE). Volume 2, Issue 4, April 2015,

Suchyadi, Y. (2017). Relationship between Work Motivation and Organizational Culture in Enhancing Professional Attitudes of Pakuan University Lecturers. Journal Of Humanities And Social Studies, 01(01), 41-45. https://doi.org/10.33751/jhss.v1i1.372

Tshosane, Abraham Nthurubele. 2011. Facilitating a learning organization : the case of a small consulting firm, Stellenbosch University.

Wulandari, Dian, Billy. T, dan Widodo.S. (2017). Relationship between Knowledge Management, Empowerment and SelfEfficacy to Learning Organization. International Journal of Managerial Studies and Research (IJMSR). Volume 5, Issue 2.

Yulk, G. (2004) Leadership in Organisations (sixth edition) New Jersey: Pearson Prentice Hall. 